\title{
STUDI KUALITAS PUPUK FOSFOR (P) DAN KALIUM (K) YANG DIJUAL DI KIOS PENYALUR RESMI PUPUK DI KABUPATEN BOGOR, CIANJUR, DAN SUKABUMI, JAWA BARAT
}

\section{Study on Quality of Inorganic Phosphorous and Potassium Fertilizers Sold at the Authorized Distributors' Kiost in Bogor, Cianjur and Sukabumi District, West Java}

\author{
Iswandi Anas1)*, Fahrizal Hazra'), Yuwan Pratama Baki2), Windi2), Heni \\ Hariyani'), Rosinta Sitepu'), dan Grahan Sugeng Aprilian')
}

\author{
1) Departemen Ilmu Tanah dan Sumberdaya Lahan, Fakultas Pertanian IPB, J1. Meranti Kampus IPB Darmaga \\ Bogor 16680 \\ 2) Alumni Departemen Ilmu Tanah dan Sumberdaya Lahan Fakultas Pertanian, Institut Pertanian Bogor, \\ Jl. Meranti, Kampus IPB Darmaga, Bogor 16680
}

\begin{abstract}
Many low quality of inorganic phosphorus $(P)$ and potassium $(K)$ fertilizers are sold at the authorized fertilizer distributors in sub-districts or villages. Selling low quality fertilizers is indeed caused disadvantages for farmers and government programs. Increasing National Rice Production Program (P2BN) and Food Security Program are certainly affected when farmers used low quality inorganic fertilizer. Government has established an institution to control fertilizers and pesticides distribution and quality at each district or town (KP3) but this institution is failure to do its task. Based on these conditions, we carried out study to evaluate the quality of phosphorus and potassium inorganic fertilizers sold at the small authorized distributors at the sub-district and village level in the District of Bogor, Cianjur dan Sukabumi. As much as 29 inorganic phosphorus and potassium fertilizers samples consisted of 10 samples of SP-36 fertilizers, 10 samples of inorganic $P$-fertilizer other than SP-36 and 9 samples of potassium fertilizer were collected. Results showed that SP-36 fertilizer which were still in the original bag sold at the small authorized kiost at sub-district or village were in good quality. The content of $\mathrm{P}_{2} \mathrm{O}_{5}$ of $\mathrm{SP}-36$ varied from $35 \%$ to $36 \% \mathrm{P}_{2} \mathrm{O}_{5}$. However, the quality of $\mathrm{P}$-fertilizers other than $\mathrm{SP}-36$ were very low, varied from 0.21 to $1.04 \% \mathrm{P}_{2} \mathrm{O}_{5}$. Four out of nine samples (44\%) of inorganic potassium fertilizer were good potassium fertilizers while $56 \%$ contain very low potassium $\left(0.02\right.$ to $\left.0.08 \% \mathrm{~K}_{2} \mathrm{O}\right)$.
\end{abstract}

Keywords: Inorganic K-fertilizer, inorganic $P$-fertilizer, quality of $P$ and $K$ inorganic fertilizer

\begin{abstract}
ABSTRAK
Peredaran pupuk anorganik fosfor (P) dan kalium (K) semakin merajalela dan memprihatinkan. Penjualan pupuk yang tidak berkualitas ini, jelas sangat merugikan petani dan pemerintah karena dapat menggagalkan panen petani dan sekaligus juga dapat menggagalkan program Pemerintah seperti Program Peningkatan Produksi Beras Nasional (P2BN) dan Program Ketahanan serta Keamanan Pangan. Pemerintah telah membentuk Komisi Pengawasan Pupuk dan Pestisida (KP3) di setiap kabupaten dan kota, yang bertugas melakukan pengawasan peredaran dan kualitas pupuk dan pestisida, akan tetapi badan ini tidak dapat menjalankan fungsinya dengan baik. Studi ini dilakukan dengan tujuan untuk mengetahui kualitas pupuk P dan K yang dijual ke masyarakat di kios resmi penyalur pupuk di tiga kabupaten yaitu Bogor, Cianjur dan Sukabumi. Kios resmi penjual pupuk dipilih berdasarkan kecamatan penyaluran pupuk subsidi untuk tanaman pangan dan hortikultura. Dalam studi ini telah diambil 29 contoh pupuk yang terdiri atas: 10 contoh pupuk SP-36, 10 contoh pupuk P selain SP-36, dan 9 contoh pupuk K. Hasil analisis contoh pupuk menunjukkan bahwa pupuk SP-36 yang dijual di kios resmi memiliki kualitas yang baik dengan kadar $\mathrm{P}_{2} \mathrm{O}_{5}$ sekitar 35-36\% $\mathrm{P}_{2} \mathrm{O}_{5}$. Namun pupuk P selain SP-36 yang terdiri dari berbagai merek yang dipasarkan di kios resmi, seluruhnya ( 9 contoh pupuk) berkualitas sangat rendah, dengan kandungan $\mathrm{P}_{2} \mathrm{O}_{5}$ berkisar dari 0.21 sampai $1.04 \% \mathrm{P}_{2} \mathrm{O}_{5}$. Hanya empat (44\%) dari sembilan contoh pupuk $\mathrm{K}$ yang berkualitas baik dengan kandungan kalium lebih dari $60 \% \mathrm{~K}_{2} \mathrm{O}$, sedangkan yang lima contoh pupuk kalium lainnya (56\%) berkualitas sangat buruk dengan kandungan kalium antara 0.02 sampai $0.08 \% \mathrm{~K}_{2} \mathrm{O}$.
\end{abstract}

Kata kunci: Pupuk anorganik K, pupuk anorganik P, kualitas pupuk anorganik 


\section{PENDAHULUAN}

Pupuk merupakan sarana produksi utama yang diperlukan petani dalam kegiatan usahataninya. Untuk menjamin kualitas pupuk yang beredar di Indonesia, produsen pupuk diwajibkan mendaftarkan pupuk yang diproduksi ke Kementrian Pertanian. Jumlah pupuk yang terdaftar di Kementerian Pertanian dan belum berakhir izin pengedarannya sampai bulan Desember 2011, berjumlah 1,477 pupuk anorganik (kimia), 533 pupuk organik, 126 pupuk hayati, dan 162 pembenah tanah (Pusat Perlindungan Varietas Tanaman dan Perizinan Pertanian, 2011).

Pengawasan kualitas pupuk merupakan suatu hal yang sangat penting dilakukan untuk menghindari pemalsuan pupuk dan menjamin mutu pupuk sesuai dengan yang tertera pada label/kantong pupuk tersebut (Suriadikarta et al., 2004). Pemerintah telah membentuk Komisi Pengawasan Pupuk dan Pestisida (KP3) di setiap kabupaten dan kota untuk melakukan pengawasan peredaran dan kualitas pupuk. KP3 ini terdiri dari berbagai instansi terkait termasuk kepolisian. Keefektifan KP3 dalam pengawasan kualitas pupuk masih sangat rendah. Dilain pihak, penyaluran pupuk baik pupuk bersubsidi maupun pupuk tidak bersubsidi, seperti pupuk $\mathrm{P}$ dan $\mathrm{K}$ sudah diatur sedemikian rupa oleh pemerintah melalui Kementerian Perdagangan dan Kementerian Pertanian.

Pupuk palsu adalah pupuk yang isi atau mutunya tidak sesuai dengan yang tertulis pada label kemasan atau meniru pupuk lain yang telah terdaftar secara legal. Pupuk anorganik (pupuk buatan) yang sering dipalsukan adalah pupuk fosfat dan pupuk kalium sedangkan pupuk N (Urea) boleh dikatakan jarang dipalsukan. Hasil penelitian Iswandi (2007, tidak dipublikasikan) yang mengambil contoh pupuk fosfat dan kalium dari berbagai daerah di Sumatera, Jawa, dan Kalimantan menemukan bahwa kualitas pupuk SP-36 dan $\mathrm{KCl}$ yang beredar di lapangan jauh dari yang seharusnya. Pemalsuan pupuk $\mathrm{P}$ dan $\mathrm{K}$ ini sampai sekarang masih berlangsung. Tindakan ini sangat merugikan petani dan pemerintah karena petani bisa mengalami kegagalan panen dan sekaligus akan menggagalkan Program Pemerintah seperti Program Peningkatan Beras Nasional (P2BN) dan Program Ketahanan serta Keamanan Pangan Pemerintah. Untuk mendapatkan gambaran mengenai kualitas pupuk $\mathrm{P}$ dan $\mathrm{K}$ yang beredar di masyarakat, maka diperlukan studi kualitas pupuk $\mathrm{P}$ dan $\mathrm{K}$. Pengambilan contoh pupuk dalam studi ini dilakukan di kios penyalur pupuk resmi di tiga kabupaten yaitu Kabupaten Bogor, Cianjur dan Sukabumi. Tujuan studi ini adalah untuk mengetahui kualitas pupuk $\mathrm{P}$ dan pupuk $\mathrm{K}$ yang dijual di kios penyalur pupuk resmi di Kabupaten Bogor, Cianjur dan Sukabumi.

\section{BAHAN DAN METODE}

Survai dilakukan di Kabupaten Bogor, Cianjur dan Sukabumi. Pemilihan lokasi didasarkan atas pertimbangan bahwa wilayah tersebut merupakan sentra pertanian tanaman pangan dan hortikultura. Di setiap kabupaten dipilih kios penyalur pupuk resmi secara acak yang terdiri dari tiga sampai empat kios pupuk di setiap kabupaten. Kios penyalur pupuk resmi yang dipilih terletak di setiap kecamatan yang merupakan sentra produksi tanaman pangan dan hortikultura, serta kios tersebut ditunjuk untuk menyalurkan pupuk bersubsidi.

Bahan dan alat yang digunakan antara lain berupa peta Kabupaten Bogor, Kabupaten Cianjur dan Kabupaten Sukabumi. Peta digunakan sebagai pedoman menentukan kios penyalur pupuk resmi yang akan diambil contoh pupuk $\mathrm{P}$ dan $\mathrm{K}$. Kamera digital digunakan untuk mengambil foto sebagai dokumentasi pupuk dan kemasan pupuk. Contoh pupuk dalam karung diambil menggunakan "tusuk tunggal" berupa besi yang berlubang untuk mengambil contoh pupuk dari karung yang belum dibuka.

Pemilihan kios penyalur pupuk resmi dibantu oleh petugas distributor pupuk resmi di kabupaten. Lokasi pengambilan contoh pupuk disajikan pada Tabel 1 .

Tabel 1. Lokasi pengambilan contoh pupuk $\mathrm{P}$ dan $\mathrm{K}$ di kios penyalur pupuk resmi

\begin{tabular}{lllll}
\hline Kabupaten & Kecamatan & Nama Kios & Pemilik & \multicolumn{1}{c}{ Alamat } \\
& Jonggol & Karya Tani & HE & Jl. Raya Kaum \\
Bogor & Cariu & Tani Berkah & - & Jl. Raya Alternatif Cianjur \\
& Ciawi & JD & Jl. Raya M. Toha Puncak \\
& Pacet & Barokah & SDM & Jl. Raya Sukanagalih \\
Cianjur & Sukaresmi & Warung Joglo & - & Jl. Mariwati Desa Cibadak \\
& Cugenang & Simpang Tani & - & Desa Cibeureum \\
& Cianjur & Rama Tani & EN & Desa Mekarsari \\
& Citamiang & Saribumi & PP GNM & J1. Otista Kel. Tipar \\
& Cisaat & Karya Tani & HE & J1. Raya Cisaat \\
& Sukalarang & Sembilan Tani & DD & J1. Raya Cianjur \\
& & & KMD & \\
\hline
\end{tabular}

Contoh pupuk diambil dari dalam karung pupuk $\mathrm{P}$ dan $\mathrm{K}$ yang belum dibuka. Tiga kilogram contoh pupuk dimasukkan ke dalam kantong plastik kapasitas $5 \mathrm{~kg}$, contoh pupuk diaduk sampai merata dan dibagi menjadi dua bagian masing-masing seberat $1.5 \mathrm{~kg}$. Masing-masing bagian tersebut dimasukkan ke dalam kantong plastik yang diberi kode contoh lokasi pengambilan. Contoh pupuk dianalisi di Laboratorium Balai Penelitian Tanah Bogor dan sebagian di simpan di Bagian Bioteknologi Tanah Departemen Ilmu Tanah dan Sumberdaya Lahan Fakultas Pertanian IPB sebagai cadangan bila diperlukan. Jumlah total contoh pupuk yang diambil ada sebanyak 29 contoh 
pupuk. Contoh pupuk yang diambil di setiap kecamatan dan kabupaten disajikan pada Tabel 2.

Tabel 2. Contoh pupuk yang diambil di setiap kecamatan dan kabupaten

\begin{tabular}{lll}
\hline Kabupaten & Kecamatan & Nama Pupuk \\
\hline Bogor & Jonggol & $\begin{array}{l}\text { SP-36; NKCl Plus Lokal; KCl } \\
\text { Kanada; OSP 3.6; SP-36 Eceran }\end{array}$ \\
& Cariu & SP-36 \\
& Ciawi & SP-36; OSP-3.6 \\
& & \\
Cianjur & Pacet & SP-36; SCP-27; CSP-36; KCl \\
& Sukaresmi & SP-36; SP 27; NKCl Kalun; NK \\
& Cugenang & SP-36; SP 36; NKCl Kirana \\
& Cianjur & SP-36; SP 27 \\
& & \\
& Citamiang & SP-36; KCl Lokal (Paramount); \\
& KCl Kanada; SP (PT. Hasya \\
& Jaya); SP 27; \\
& Cisaat & SP-36; KCl Kanada \\
& Sukalarang & SP-36 \\
& &
\end{tabular}

Untuk mengetahui kandungan $\mathrm{P}_{2} \mathrm{O}_{5}$ total, kandungan $\mathrm{K}_{2} \mathrm{O}$ total dan kadar air pupuk $\mathrm{P}$ dan pupuk $\mathrm{K}$ maka dilakukan analisis pupuk di Laboratorium Balai Penelitian Tanah Bogor, Balai Besar Penelitian Sumberdaya Lahan Pertanian, Badan Penelitian dan Pengembangan Kementrian Pertanian, dengan menggunakan metoda baku.

\section{HASIL DAN PEMBAHASAN}

\section{Kualitas Pupuk P yang Beredar di Kabupaten Bogor, Cianjur, dan Sukabumi}

Hasil analisis contoh pupuk SP-36 yang diambil dari karung yang masih utuh dan analisis pupuk $\mathrm{P}$ lain termasuk pupuk SP-36 eceran yang dijual di kios penyalur pupuk resmi di Kabupaten Bogor, Cianjur dan Sukabumi disajikan berturut-turut pada Tabel 3 dan Tabel 4. Semua analisis contoh pupuk $\mathrm{P}$ ini dilakukan di laboratorium Balai Penelitian Tanah (Balittanah) Jl. Juanda, Bogor. Data yang dicantumkan adalah berupa nomor laboratorium contoh pupuk, status kios tempat pengambilan contoh pupuk yang dianalisis, nama atau merek pupuk fosfat yang dijual, izin untuk mengedarkan pupuk kepada masyarakat, klaim dari produsen terutama kandungan hara, hasil analisis kandungan $\mathrm{P}_{2} \mathrm{O}_{5}$ dan hasil analisis kadar air, kode produksi dari karung contoh (Bag Code), Rencana Definitif Kebutuhan Pupuk (RDKK), dan harga pupuk per kilogram untuk setiap jenis pupuk.

Kualitas pupuk $\mathrm{K}$ yang beredar di Kabupaten Bogor, Cianjur dan Sukabumi pada bulan Januari 2012 yang diambil dari kios penyalur pupuk disajikan pada Tabel 5. Analisis contoh pupuk K dan data yang dicantumkan pada Tabel analisis contoh pupuk $\mathrm{K}$ ini sama dengan analisis pupuk SP-36 (Tabel 3) dan pupuk Plainnya (Tabel 4).
Berdasarkan hasil pengamatan di lapangan, ternyata di kios penyalur pupuk resmi, tidak saja dijual pupuk $\mathrm{P}$ dan $\mathrm{K}$ yang berkualitas, tetapi juga banyak sekali pupuk $\mathrm{P}$ dan $\mathrm{K}$ yang tidak berkualitas yang dipasarkan kepada petani. Di Kabupaten Cianjur dijumpai pupuk $\mathrm{P}$ dan K, seperti SP 27 produksi Palagung, NK Fertybumi, dan $\mathrm{NKCl} \mathrm{Kalun} \mathrm{(Gambar} \mathrm{1)} \mathrm{yang} \mathrm{tidak} \mathrm{mencantumkan}$ kadar $\mathrm{P}_{2} \mathrm{O}_{5}$ maupun kadar $\mathrm{K}_{2} \mathrm{O}$ pada karungnya. Hal ini mengakibatkan petani pembeli tidak bisa mengetahui mutu dari pupuk tersebut.

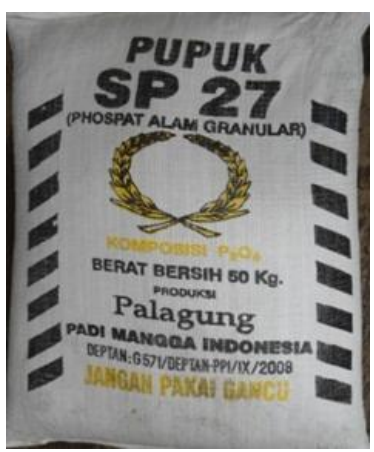

(a)

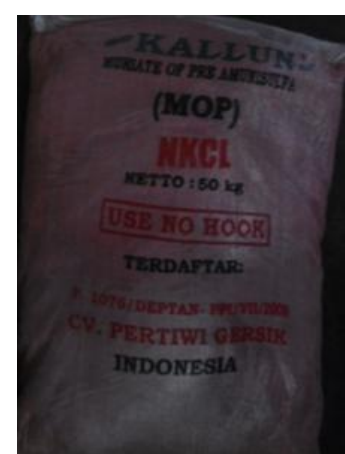

(b)



(c)

Gambar 1. Kemasan pupuk SP 27 (a), NKCl Kalun (b) dan NK Fetrybumi (c) yang tidak mencantumkan kadar unsur hara yang dikandung pupuk tersebut.

Berdasarkan hasil analisis kimia kandungan unsur hara dari contoh pupuk yang dilakukan di Balai Penelitian Tanah (Balittanah), kandungan $\mathrm{P}_{2} \mathrm{O}_{5}$ total pada pupuk SP36 antara 35.03-36.15\% (Tabel 3). Contoh pupuk ini diambil dari karung yang masih utuh. Data ini menunjukkan bahwa kualitas pupuk SP-36 yang dijual di kios penyalur resmi yang terdapat di dalam karung yang masih utuh, adalah pupuk SP-36 yang berkualitas baik . Akan tetapi ada lima contok pupuk SP-36 yang kadar airnya melebihi 5\% yaitu contoh pupuk SP-36 yang diambil dari Kecamatan Sukalarang, Jonggol, Ciawi, Pacet, dan Cianjur (Tabel 3). 
Tabel 3. Studi kualitas pupuk P (SP-36) yang beredar di Kabupaten Bogor, Cianjur, dan Sukabumi pada bulan Januari 2012

\begin{tabular}{|c|c|c|c|c|c|c|c|c|c|}
\hline \multirow[t]{2}{*}{ No. } & \multirow[t]{2}{*}{ No. Lab } & \multirow[t]{2}{*}{ Kode } & \multirow{2}{*}{$\begin{array}{c}\text { Status Kios } \\
\text { (Resmi/Tidak ) Nama Kios }\end{array}$} & \multirow{2}{*}{$\begin{array}{l}\text { Nama/ } \\
\text { Merek } \\
\text { Pupuk }\end{array}$} & \multirow[t]{2}{*}{ Izin Edar PPI } & \multirow[t]{2}{*}{ Klaim } & \multicolumn{2}{|c|}{ Analisis Pupuk P } & \multirow{2}{*}{$\begin{array}{c}\text { Bag Code } \\
\text { /RDKK/ Harga }\left(\mathrm{Rp} \mathrm{kg}^{-1}\right)\end{array}$} \\
\hline & & & & & & & $\mathrm{P}_{2} \mathrm{O}_{5}(\%)$ & Kadar Air (\%) & \\
\hline \multicolumn{10}{|c|}{ Pupuk SP-36 PT Petrokimia Gresik } \\
\hline 1. & P.0132 & A1 & $\begin{array}{l}\text { Kios Resmi PT Petrokimia } \\
\text { Gresik }\end{array}$ & SP-36 & $\begin{array}{l}\text { G 972/DEPTAN- } \\
\text { PPI/XI/2009 }\end{array}$ & $\mathrm{P}_{2} \mathrm{O}_{5} 36 \%$ & 35.53 & 4.62 & 40110102 280067864/-/2000 \\
\hline 2. & P.0133 & A2 & $\begin{array}{l}\text { Kios Resmi PT Petrokimia } \\
\text { Gresik }\end{array}$ & SP-36 & $\begin{array}{l}\text { G 972/DEPTAN- } \\
\mathrm{PPI} / \mathrm{XI} / 2009\end{array}$ & $\mathrm{P}_{2} \mathrm{O}_{5} 36 \%$ & 35.82 & 4.98 & 40110102 260071316/-/2000 \\
\hline 3. & P. 0134 & A3 & $\begin{array}{l}\text { Kios Resmi PT Petrokimia } \\
\text { Gresik }\end{array}$ & SP-36 & $\begin{array}{l}\text { G 972/DEPTAN- } \\
\text { PPI/XI/2009 }\end{array}$ & $\mathrm{P}_{2} \mathrm{O}_{5} 36 \%$ & 35.77 & 5.04 & tanpa bag code/-/2000 \\
\hline 4. & P.0135 & B1 & $\begin{array}{l}\text { Kios Resmi PT Petrokimia } \\
\text { Gresik }\end{array}$ & SP-36 & $\begin{array}{l}\text { G 972/DEPTAN- } \\
\mathrm{PPI} / \mathrm{XI} / 2009\end{array}$ & $\mathrm{P}_{2} \mathrm{O}_{5} 36 \%$ & 35.04 & 5.74 & $39301203272043058 /-/ 2500$ \\
\hline 5. & P.0136 & B2 & $\begin{array}{l}\text { Kios Resmi PT Petrokimia } \\
\text { Gresik }\end{array}$ & SP-36 & $\begin{array}{l}\text { G 972/DEPTAN- } \\
\text { PPI/XI/2009 }\end{array}$ & $\mathrm{P}_{2} \mathrm{O}_{5} 36 \%$ & 36.15 & 3.01 & $39311201272051132 /-/ 2000$ \\
\hline 6. & P.0137 & B3 & $\begin{array}{l}\text { Kios Resmi PT Petrokimia } \\
\text { Gresik }\end{array}$ & SP-36 & $\begin{array}{l}\text { G 972/DEPTAN- } \\
\mathrm{PPI} / \mathrm{XI} / 2009\end{array}$ & $\mathrm{P}_{2} \mathrm{O}_{5} 36 \%$ & 35.26 & 5.23 & $40120103280069917 /-/ 2200$ \\
\hline 7. & P.0138 & $\mathrm{C} 1$ & $\begin{array}{l}\text { Kios Resmi PT Petrokimia } \\
\text { Gresik }\end{array}$ & SP-36 & $\begin{array}{l}\text { G 972/DEPTAN- } \\
\mathrm{PPI} / \mathrm{XI} / 2009\end{array}$ & $\mathrm{P}_{2} \mathrm{O}_{5} 36 \%$ & 35.03 & 5.84 & 40033102 260017673/-/2000 \\
\hline 8. & P.0139 & $\mathrm{C} 2$ & $\begin{array}{l}\text { Kios Resmi PT Petrokimia } \\
\text { Gresik }\end{array}$ & SP-36 & $\begin{array}{l}\text { G 972/DEPTAN- } \\
\mathrm{PPI} / \mathrm{XI} / 2009\end{array}$ & $\mathrm{P}_{2} \mathrm{O}_{5} 36 \%$ & 35.67 & 4.54 & $40020101280009894 /-/ 2500$ \\
\hline 9. & P.0140 & C3 & $\begin{array}{l}\text { Kios Resmi PT Petrokimia } \\
\text { Gresik }\end{array}$ & SP-36 & $\begin{array}{l}\text { G 972/DEPTAN- } \\
\mathrm{PPI} / \mathrm{XI} / 2009\end{array}$ & $\mathrm{P}_{2} \mathrm{O}_{5} 36 \%$ & 35.99 & 4.86 & 40060102 250034452/-/2500 \\
\hline 10. & P.0141 & $\mathrm{C} 4$ & $\begin{array}{l}\text { Kios Resmi PT Petrokimia } \\
\text { Gresik }\end{array}$ & SP-36 & $\begin{array}{l}\text { G 972/DEPTAN- } \\
\mathrm{PPI} / \mathrm{XI} / 2009\end{array}$ & $\mathrm{P}_{2} \mathrm{O}_{5} 36 \%$ & 36.12 & 5.39 & tanpa bag code/-/2200 \\
\hline
\end{tabular}

Tabel 4. Studi kualitas pupuk P (selain SP-36) yang beredar di Kabupaten Bogor, Cianjur, dan Sukabumi pada bulan Januari 2012

\begin{tabular}{|c|c|c|c|c|c|c|c|c|c|}
\hline \multirow[t]{2}{*}{ No. } & \multirow[t]{2}{*}{ No. Lab } & \multirow[t]{2}{*}{ Kode } & \multirow{2}{*}{$\begin{array}{c}\text { Status (Resmi/Tidak ) dan } \\
\text { Nama Kios }\end{array}$} & \multirow{2}{*}{$\begin{array}{l}\text { Merek } \\
\text { Pupuk }\end{array}$} & \multirow[t]{2}{*}{ Izin Edar PPI } & \multirow[t]{2}{*}{ Klaim } & \multicolumn{2}{|c|}{ Analisis Pupuk P } & \multirow{2}{*}{$\begin{array}{c}\text { Bag Code } \\
\text { /RDKK/ Harga }(\mathrm{Rp} \\
\left.\mathrm{kg}^{-1}\right) \\
\end{array}$} \\
\hline & & & & & & & $\mathrm{P}_{2} \mathrm{O}_{5}(\%)$ & $\begin{array}{c}\text { Kadar Air } \\
(\%)\end{array}$ & \\
\hline 1. & P.0151 & I.1.3 & WT & S-P & Tidak Ada* & Tidak tercantum kadar $\mathrm{P}_{2} \mathrm{O}_{5}$ & 0.34 & 2.82 & $-/-/ 2000$ \\
\hline 2. & P.0152 & I.1.4 & WT & SP-27 & Tidak Ada* & Tidak tercantum kadar $\mathrm{P}_{2} \mathrm{O}_{5}$ & 0.26 & 1.85 & $-/-/ 2000$ \\
\hline 3. & P.0153 & II.1.3 & KT & OSP-3.6 & $\begin{array}{l}\text { G 185/DEPTAN- } \\
\text { PPI/IX/2006 } \\
\text { September } 2011\end{array}$ & $\begin{array}{l}\text { Kadar } \mathrm{P}_{2} \mathrm{O}_{5} \text { diklaim lebih tinggi dari } \\
\text { hasil analisis }\end{array}$ & 0.21 & 2.98 & $-/-/ 2000$ \\
\hline 4. & P. 0154 & II.1.4 & $\begin{array}{l}\text { KT (Kios Resmi PT Petrokimia } \\
\text { Gresik) }\end{array}$ & $\begin{array}{l}\text { SP-36 } \\
\text { (eceran) }\end{array}$ & $\begin{array}{l}\text { G 972/DEPTAN- } \\
\text { PPI/XI/2009 }\end{array}$ & Tidak tercantum kadar $\mathrm{P}_{2} \mathrm{O}_{5}$ & 35.25 & 5.37 & $-/-/ 2000$ \\
\hline 5. & P.0155 & II. 2 & $\begin{array}{l}\text { CI (Kios Resmi PT Petrokimia } \\
\text { Gresik) }\end{array}$ & OSP-3.6 & $\begin{array}{l}\text { G 185/DEPTAN- } \\
\text { PPI/IX/2006 } \\
\text { September } 2011\end{array}$ & $\begin{array}{l}\text { Kadar } \mathrm{P}_{2} \mathrm{O}_{5} \text { diklaim lebih tinggi dari } \\
\text { hasil analisis }\end{array}$ & 1.04 & 8.68 & $-/-/ 1100$ \\
\hline 6. & P.0156 & III.1.1 & $\begin{array}{l}\text { BRK(Kios Resmi PT } \\
\text { Petrokimia Gresik) }\end{array}$ & SCP-27 & Tidak Ada* & Tidak tercantum kadar $\mathrm{P}_{2} \mathrm{O}_{5}$ & 0.37 & 8.46 & $-/-/ 800$ \\
\hline 7. & P.0157 & III. 1.2 & $\begin{array}{l}\text { BRK (Kios Resmi PT } \\
\text { Petrokimia Gresik) }\end{array}$ & CSP-36 & Tidak Ada* & $\begin{array}{l}\text { Kadar } \mathrm{P}_{2} \mathrm{O}_{5} \text { diklaim lebih tinggi dari } \\
\text { hasil analisis }\end{array}$ & 0.41 & 0.97 & $-/-/ 1300$ \\
\hline 8. & P.0158 & III. 2.3 & $\begin{array}{l}\text { WJ (Kios Resmi PT Petrokimia } \\
\text { Gresik) }\end{array}$ & SP 27 & Tidak Ada* & Tidak tercantum kadar $\mathrm{P}_{2} \mathrm{O}_{5}$ & 0.37 & 2.24 & $-/-/ 1100$ \\
\hline
\end{tabular}




\begin{tabular}{|c|c|c|c|c|c|c|c|c|c|}
\hline \multirow[t]{2}{*}{ No. } & \multirow[t]{2}{*}{ No. Lab } & \multirow[t]{2}{*}{ Kode } & \multirow{2}{*}{$\begin{array}{l}\text { Status (Resmi/Tidak ) dan } \\
\text { Nama Kios }\end{array}$} & \multirow{2}{*}{$\begin{array}{l}\text { Merek } \\
\text { Pupuk }\end{array}$} & \multirow[t]{2}{*}{ Izin Edar PPI } & \multirow[t]{2}{*}{ Klaim } & \multicolumn{2}{|c|}{ Analisis Pupuk P } & \multirow{2}{*}{$\begin{array}{c}\text { Bag Code } \\
\text { /RDKK/ Harga (Rp } \\
\left.\mathrm{kg}^{-1}\right)\end{array}$} \\
\hline & & & & & & & $\mathrm{P}_{2} \mathrm{O}_{5}(\%)$ & $\begin{array}{c}\text { Kadar Air } \\
(\%)\end{array}$ & \\
\hline 9. & P.0159 & III. 3.4 & $\begin{array}{l}\text { ST (Kios Resmi PT Petrokimia } \\
\text { Gresik) }\end{array}$ & SP-36 & Tidak Ada* & $\begin{array}{l}\text { Kadar } \mathrm{P}_{2} \mathrm{O}_{5} \text { diklaim lebih tinggi dari } \\
\text { hasil analisis }\end{array}$ & 0.34 & 7.09 & $-/-/ 1100$ \\
\hline 10. & P. 0160 & III. 4.3 & $\begin{array}{l}\text { RT (Kios Resmi PT Petrokimia } \\
\text { Gresik) }\end{array}$ & SP 27 & Tidak Ada* & Tidak tercantum kadar $\mathrm{P}_{2} \mathrm{O}_{5}$ & 0.36 & 0.53 & $-/-/ 1100$ \\
\hline
\end{tabular}

Tidak Ada* : Tidak dalam Bentuk Pendaftaran Izin Edar pupuk dari PPI (Pusat Perizinan dan Investasi, Kementrian Pertanian RI)

Tabel 5. Studi kualitas pupuk K yang beredar di Kabupaten Bogor, Cianjur, dan Sukabumi pada bulan Januari 2012

\begin{tabular}{|c|c|c|c|c|c|c|c|c|c|}
\hline \multirow{2}{*}{ No. } & \multirow{2}{*}{ No. Lab } & \multirow{2}{*}{ Kode } & \multirow{2}{*}{$\begin{array}{c}\text { Status (Resmi/Tidak ) dan } \\
\text { Nama Kios }\end{array}$} & \multirow{2}{*}{$\begin{array}{l}\text { Merek } \\
\text { Pupuk }\end{array}$} & \multirow{2}{*}{ Izin Edar PPI } & \multirow{2}{*}{ Klaim } & \multicolumn{2}{|c|}{$\begin{array}{c}\text { Hasil Analisis } \\
\text { Pupuk K } \\
\end{array}$} & \multirow{2}{*}{$\begin{array}{c}\text { Bag Code } \\
\text { /RDKK/ Harga (Rp } \\
\left.\mathrm{kg}^{-1}\right)\end{array}$} \\
\hline & & & & & & & $\begin{array}{c}\text { Pupuk K } \\
(\%)\end{array}$ & Kadar Air (\%) & \\
\hline 1. & P.0142 & I.1.1 & WT/Tidak resmi & KCl Lokal (Para-mount) & Tidak Ada* & $\begin{array}{l}\text { Tidak tercantum } \\
\text { kadar } \mathrm{K}_{2} \mathrm{O}\end{array}$ & 0.06 & 4.52 & $-/-/ 2500$ \\
\hline 2. & P.0143 & I. 1.2 & WT/Tidak resmi & KCl Mahkota & $\begin{array}{l}\text { G } \quad 661 / \text { DEPTAN- } \\
\text { PPI/XII/2008 }\end{array}$ & Kadar $65 \% \mathrm{~K}_{2} \mathrm{O}$ & 60.94 & 1.10 & $-/-/ 15000$ \\
\hline 3. & P.0144 & I.2.1 & $\begin{array}{l}\text { KT (Kios Resmi PT Petrokimia } \\
\text { Gresik) }\end{array}$ & KCl Mahkota & $\begin{array}{l}\text { G } \quad 661 / \text { DEPTAN- } \\
\text { PPI/XII/2008 }\end{array}$ & Kadar $65 \% \mathrm{~K}_{2} \mathrm{O}$ & 61.43 & 0.25 & $-/-/ 7000$ \\
\hline 4. & P.0145 & II.1.1 & $\begin{array}{l}\text { KT (Kios Resmi PT Petrokimia } \\
\text { Gresik) }\end{array}$ & NKCl Plus Lokal & Tidak Ada* & $\begin{array}{l}\text { Tidak tercantum kadar } \\
\mathrm{K}_{2} \mathrm{O}\end{array}$ & 0.03 & 4.70 & $-/-/ 2000$ \\
\hline 5. & P.0146 & II.1.2 & $\begin{array}{l}\text { KT (Kios Resmi PT Petrokimia } \\
\text { Gresik) }\end{array}$ & KCl Mahkota & $\begin{array}{l}\text { G } 661 / \text { DEPTAN- } \\
\text { PPI/XII/2008 }\end{array}$ & Kadar $65 \% \mathrm{~K}_{2} \mathrm{O}$ & 61.83 & 0.22 & $-/-/ 7000$ \\
\hline 6. & P.0147 & III. 1.8 & $\begin{array}{l}\text { BRK(Kios Resmi PT } \\
\text { Petrokimia Gresik) }\end{array}$ & KCl Mahkota & $\begin{array}{l}\text { G 661/DEPTAN- } \\
\text { PPI/XII/2008 }\end{array}$ & Kadar $65 \% \mathrm{~K}_{2} \mathrm{O}$ & 61.43 & 0.25 & $-/-/ 6000$ \\
\hline 7. & P. 0148 & III. 2.6 & $\begin{array}{l}\text { WJ (Kios Resmi PT Petrokimia } \\
\text { Gresik) }\end{array}$ & NK Fertybumi & Tidak ada* & $\begin{array}{l}\text { Tidak tercantum kadar } \\
\mathrm{K}_{2} \mathrm{O}\end{array}$ & 0.02 & 5.59 & $-/-/ 1300$ \\
\hline 8. & P.0149 & III.2.7 & $\begin{array}{l}\text { WJ (Kios Resmi PT Petrokimia } \\
\text { Gresik) }\end{array}$ & $\mathrm{NKCl}$ Kallun & Tidak ada* & $\begin{array}{l}\text { Tidak tercantum kadar } \\
\mathrm{K}_{2} \mathrm{O}\end{array}$ & 0.03 & 3.99 & $-/-/ 1300$ \\
\hline 9. & P. 0150 & III.3.5 & $\begin{array}{l}\text { ST (Kios Resmi PT Petrokimia } \\
\text { Gresik) }\end{array}$ & $\mathrm{NKCl}$ Kirana & Tidak ada* & $\begin{array}{l}\text { Tidak tercantum kadar } \\
\mathrm{K}_{2} \mathrm{O}\end{array}$ & 0.08 & 4.83 & $-/-/ 1200$ \\
\hline
\end{tabular}

Tidak Ada* : Tidak dalam Bentuk Pendaftaran Izin Edar pupuk dari PPI (Pusat Perizinan dan Investasi, Kementrian Pertanian RI) 
Hasil analisis contoh pupuk P-lainnya selain pupuk SP-36 yang dijual di kios penyalur pupuk resmi sangat mengkhawatirkan (Tabel 4). Satu pupuk SP-36 yang dijual secara eceran memiliki surat izin edar dan kualitasnya baik. Kandungan $\mathrm{P}_{2} \mathrm{O}_{5}$ pupuk SP-36 eceran ini adalah $35.25 \%$ yang berarti sesuai dengan kandungan yang seharusnya. Akan tetapi dua pupuk P-lainnya yang juga mempunyai izin edar yang dikeluarkan oleh Pusat Perizinan dan Investasi (PPI) Kementrian Pertanian mempunyai kualitas yang rendah dimana kadar $\mathrm{P}_{2} \mathrm{O}_{5}$ yang diklaim tidak sesuai dengan hasil analisis pupuk yang dilakukan. Hasil analisis pupuk jauh dibawah nilai yang nilai yang dicantumkan di karung pupuk. Pupuk tersebut adalah OSP 3.6 yang dijual di kios Kharisma Tani dan Kios Ciawi Indah. Kios Ciawi Indah adalah kios penyalur pupuk resmi. Kandungan $\mathrm{P}$ dari pupuk OSP 3.6 yang dijual disini hanya $1.04 \% \mathrm{P}_{2} \mathrm{O}_{5}$. Pupuk OSP-3.6 ditemukan di Kecamatan Ciawi, Kabupaten Bogor di kios Ciawi Indah. Pemilihan nama pupuk OSP 3.6 juga ada indikasi untuk menyerupai nama pupuk SP-36. Pupuk ini sudah mendapatkan surat izin edar resmi dari PPI Kementan dengan nomor G 185/DEPTAN-PPI/IX/2006 bulan September 2011. Pupuk P-lainnya yang dijual di kios penyalur pupuk ini umunya ( 7 contoh pupuk dari 10 contoh pupuk) atau $70 \%$ tidak mempunyai izin dari PPI. Nama pupuk $\mathrm{P}$ yang tidak berkualitas yang dijual di kios penyalur pupuk resmi adalah S-P (1 kios), SP-27 (3 kios), SCP-27 (1 kios), CSP-36 (1 kios) dan SP-36 (1 kios). Semua pupuk P-lainnya ini tidak mempunyai surat izin edar resmi. Kandungan $\mathrm{P}_{2} \mathrm{O}_{5}$-nya umumnya kurang dari $0.41 \%$. Selain kadar $\mathrm{P}_{2} \mathrm{O}_{5}$ yang rendah, pupuk P-lainnya yang dijual di kios resmi penyalur pupuk ini juga mempunyai kadar air yang tinggi mencapai $8.68 \%$ (OSP3.6) seperti pupuk P-lainnya yang dijual di kios Ciawi Indah. Pupuk P yang bermerek SP 27 kandungan $\mathrm{P}_{2} \mathrm{O}_{5}$ totalnya hanya mencapai $0.37 \%$. Pupuk OSP-3.6 produksi Karya Tani Indonesia memiliki kandungan $\mathrm{P}_{2} \mathrm{O}_{5}$ hanya $0.21 \%$. Hal ini tidak sesuai dengan kandungan produk yang didaftarkan kepada PPI Kementan. Pupuk OSP-3.6 didaftarkan di PPI dengan nomor pendaftaran G185/DEPTAN-PPI/XI/2009 bulan September 20011 dengan kadar $\mathrm{P}_{2} \mathrm{O}_{5} 10.10 \%$. Kenyataannya pupuk OSP-3.6 ini hanya mengandung $0.21 \% \quad \mathrm{P}_{2} \mathrm{O}_{5}$. Tentu saja hal ini sangat merugikan petani dan pemerintah. Di Kecamatan Cugenang, Kabupaten Cianjur ada pupuk dengan merek SP-36 yang dikemas dalam karung dan logo yang mirip dengan pupuk SP-36 yang disubsidi pemerintah (Gambar 2). Hasil analisis kadar $P$ pupuk ini sangat rendah yaitu hanya mengandung $0.34 \% \quad \mathrm{P}_{2} \mathrm{O}_{5}$ dengan kadar air yang tinggi yaitu $7.09 \%$. Pupuk ini di produksi oleh CV. Putri Kirana Gresik dengan kandungan $\mathrm{P}_{2} \mathrm{O}_{5}$ total yang tertulis pada label sebesar $16 \%$ tetapi setelah dianalisis kandungan $\mathrm{P}_{2} \mathrm{O}_{5}$ total hanya $0.34 \%$.

Pupuk $\mathrm{P}$ yang tidak berkualitas ini dijual dengan harga berkisar dari Rp 800 sampai $\mathrm{Rp} 2,000 \mathrm{~kg}^{-1}$ (Tabel 4). Harga penjualan pupuk $P$ yang tidak berkualitas ini hampir menyamai harga pupuk SP-36 yang berkualitas dan bersubsidi yaitu berkisar dari Rp 2,000 sampai Rp 2,500 $\mathrm{kg}^{-1} \quad$ (Tabel 3). Tentu saja tindakan ini merugikan petani bukan saja dari harga yang tinggi, kualitas pupuk yang tidak baik tetapi juga panen petani yang pasti tidak sesuai dengan yang diharapkan petani.

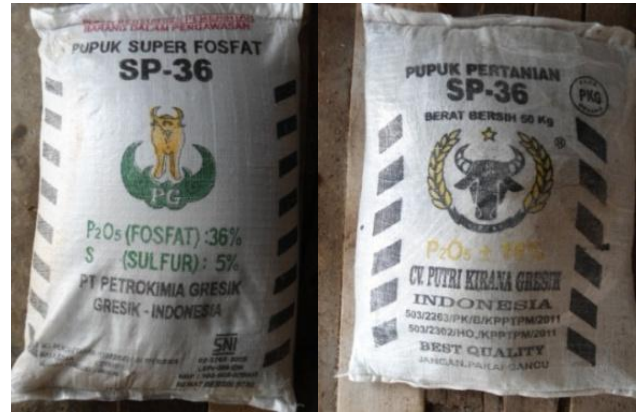

(a)

(b)

Gambar 2. Pupuk SP-36 yang disubsidi Pemerintah (a), dan pupuk "SP-36" yang dikemas mirip dengan pupuk SP-36 bersubsidi (b)

Selain itu, di Kecamatan Citamiang juga ditemukan pupuk $\mathrm{P}$ yang tidak berkualitas yaitu SP-27 dengan kandungan $\mathrm{P}_{2} \mathrm{O}_{5}$ totalnya hanya sebesar $0.36 \%$, dan tidak terdaftar di Kementerian Pertanian RI (Gambar $3)$.

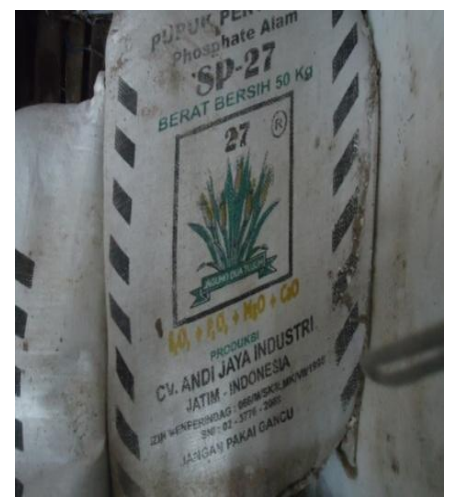

Gambar 3. Pupuk SP-27 yang tidak terdaftar di Pusat Perizinan dan Investasi Kementerian Pertanian RI

Kualitas Pupuk Kalium (K) yang Beredar di Kabupaten Bogor, Cianjur, dan Sukabumi. Dari sembilan contoh pupuk kalium yang diambil dalam studi ini, empat $(45 \%)$ pupuk kalium mempunyai izin edar dan lima (55\%) pupuk tidak mempunyai izin edar (Tabel 5). Pupuk yang mempunyai izin edar adalah merek $\mathrm{KCl}$ Mahkota. Kandungan $\mathrm{K}_{2} \mathrm{O}$ pupuk ini berkisar dari $60.94 \%$ sampai $61.83 \%$ artinya pupuk ini berkualitas baik dan memenuhi persyaratan dari Pusat Perizinan dan Investasi (PPI) Kementrian Pertanian. Pupuk kalium lainnya dipasarkan tanpa memiliki surat izin edar. Salah satu contohnya adalah KCl Lokal Paramount. Pupuk kalium ini dijual di kios Warga Tani dengan kandungan $\mathrm{K}_{2} \mathrm{O}$ yang hanya $0.06 \%$. Di beberapa kios penyalur pupuk resmi lainnya ditemukan pupuk $\mathrm{K}$ yang tidak berkualitas. Kios Karya Tani menjual pupuk NKCl Plus Lokal dengan kadar $\mathrm{K}_{2} \mathrm{O}$ yang hanya $0.03 \%$. Pupuk NK Fertybumi di jual di Kios Warung Joglo dengan kadar $0.02 \% \quad \mathrm{~K}_{2} \mathrm{O}$. Kios ini juga menjual pupuk $\mathrm{K}$ dengan merek $\mathrm{NKCl}$ Kalun yang mengandung $0.03 \% \mathrm{~K}_{2} \mathrm{O}$. Kios Simpang Tani menjual pupuk $\mathrm{NKCl}$ Kirana dengan kadar $\mathrm{K}_{2} \mathrm{O}$ yang juga sangat rendah yaitu $0.08 \%$. Kelima pupuk $\mathrm{K}$ ini adalah pupuk kalim yang kualitasnya sangat buruk.

Harga eceran pupuk kalium yang berkualitas yang kadar $\mathrm{K}_{2} \mathrm{O}$ lebih tinggi dari $60 \%$ berkisar dari $\mathrm{Rp}$ 7,000 sampai Rp15,000 per kilogram. Harga pupuk kalium 
yang tidak berkualitas berkisar dari Rp 1,200 (NKCl Kirana) sampai $\mathrm{Rp} 2,500$ ( $\mathrm{KCl}$ lokal Paramount) per kilogramnya. Dilihat sepintas lalu harga pupuk $\mathrm{KCl}$ yang tidak berkualitas ini termasuk murah namun kalau dihitung berdasarkan kandungan $\mathrm{K}_{2} \mathrm{O}$ di dalamnya, maka pupuk $\mathrm{K}$ yang tidak berkualitas ini sangatlah mahal. Sebagai contoh, pupuk $\mathrm{KCl}$ Lokal Paramount dengan harga $\mathrm{Rp}$ $2,500 \mathrm{~kg}^{-1}$ dengan kandungan $\mathrm{K}_{2} \mathrm{O}$ yang hanya $0.06 \%$, bila dihitung kadar $\mathrm{K}_{2} \mathrm{O} 60 \%$ maka harga pupuk $\mathrm{KCl}$ Lokal Paramount dengan kadar $60 \% \quad \mathrm{~K}_{2} \mathrm{O}$, sama dengan $\mathrm{Rp}$ $2,500,000$ yang artinya 1,000 kali lebih mahal dari pupuk $\mathrm{KCl}$ yang berkualitas. Hal ini tentu sangat merugikan petani, bukan saja dari segi uang yang harganya sampai 1,000 kali lipat tetapi juga kegagalan panen yang akan dialami oleh petani. Penggunaan pupuk yang tidak berkualitas ini tentunya juga akan menggagalkan program peningkatan produksi pertanian yang dijalankan pemerintah.

Pengetahuan petani mengenai pupuk dan harga pupuk seringkali tidak memadai. Kebanyakan petani datang ke kios untuk membeli pupuk yang mirip dengan pupuk $\mathrm{P}$ atau pupuk $\mathrm{K}$ dan sering membeli pupuk dengan pedoman harga pupuk yang murah. Dengan kata lain bagi petani, pertimbangan utama dalam membeli pupuk adalah harga pupuk sedangkan kualitas tidak menjadi pertimbangan petani.

Maraknya peredaran pupuk yang tidak berkualitas di Kabupaten Bogor, Cianjur, dan Sukabumi membuktikan bahwa kontrol terhadap kualitas pupuk yang beredar tidak ada atau masih sangat kurang. Hal ini membutuhkan perhatian dari semua pihak khususnya dari pemerintah untuk lebih mengawasi mutu pupuk dan dilain pihak meningkatkan pengetahuan petani mengenai pentingnya kualitas pupuk.

\section{SIMPULAN}

1. Pupuk SP-36 yang diproduksi PT Petro Kimia Gresik yang masih dalam karung yang dijual di kios resmi penyalur pupuk merupakan pupuk yang berkualitas baik sesuai dengan standar.

2. Pupuk P (selain SP-36) dan pupuk K yang tidak berkualitas (kandungan $\mathrm{P}$ dan $\mathrm{K}$ yang tidak sesuai dengan izin edar) banyak dijual di kios resmi penyalur pupuk. Beberapa diantara pupuk $\mathrm{P}$ dan $\mathrm{K}$ yang dijual ini tidak memperoleh izin edar dari Pusat Perizinan dan Investasi, Kementrian Pertanian RI.

3. Pengetahuan petani mengenai kualitas pupuk terutama pupuk $\mathrm{P}$ dan $\mathrm{K}$ masih sangat rendah.

4. Kemasan/karung pupuk $\mathrm{P}$ tiruan dan $\mathrm{K}$ tiruan yang tidak mencantumkan kadar $\mathrm{P}_{2} \mathrm{O}_{5}$ total (pupuk $\mathrm{P}$ tiruan) dan kadar $\mathrm{K}_{2} \mathrm{O}$ totalnya (pupuk $\mathrm{K}$ tiruan) atau meniru label dan logo pupuk asli banyak ditemukan di kios penyalur pupuk resmi di Kabupaten Bogor, Cianjur dan Sukabumi.

5. Di Kecamatan Cugenang, Kabupaten Cianjur ditemukan pupuk dengan merek "SP-36" yang kemasannya mirip dengan pupuk SP-36 asli yang bersubsidi yang kandungan $\mathrm{P}_{2} \mathrm{O}_{5}$ nya sangat rendah $(0.34 \%)$

\section{DAFTAR PUSTAKA}

Iswandi, A. 2007. Kualitas pupuk buatan dari berbagai daerah. Hasil Penelitian Mandiri. (tidak dipublikasikan).

Peraturan Menteri 51 Pertanian No. 6 Tahun 2011. Kebutuhan dan Harga Eceran Tertinggi (HET) Pupuk Bersubsidi untuk Sektor Pertanian Tahun Anggaran 2011. Peraturan Menteri Pertanian No. 6 Tahun 2011. Jakarta.

Pusat Perizinan dan Investasi c/q Pusat Perlindungan Varietas Tanaman dan Perizinan Pertanian. 2011. Pupuk Anorganik, Organik, Pembenah Tanah dan Hayati Terdaftar. Pusat Perlindungan Varietas Tanaman dan Perizinan Pertanian, Sekertaris Jenderal Kementerian Pertanian Republik Indonesia, Jakarta. 373 halaman.

Suriadikarta, D.A., D. Setyorini, dan W. Hartatik. 2004. Petunjuk Teknis Uji Mutu dan Efektivitas Pupuk Alternatif Anorganik. Balai Penelitian Tanah. Bogor. 